\title{
PENGARUH KIE MENGGUNAKAN BUKU SAKU TERHADAP PENINGKATAN PENGETAHUAN AKSEPTOR KB HORMONAL DI PUSKESMAS SOREANG KABUPATEN BANDUNG TAHUN 2019
}

\author{
Istiqomah M Putri $^{1)}$, Merry Wijaya ${ }^{2)}$, Astuti Dyah Bestari ${ }^{3)}$ \\ ${ }^{1,2,3)}$ Fakultas Kedokteran Prodi DIV Kebidanan Universitas Padjajaran \\ ${ }^{1}$ istiqomahmegaputrii@gmail.com \\ ${ }^{2}$ merry_wijaya0605@yahoo.com \\ 3 astutibestari86@gmail.com
}

\begin{abstract}
ABSTRAK
Hipertensi merupakan penyakit tidak menular yang banyak terjadi dan mempunyai tingkat mortalitas yang cukup tinggi serta mempengaruhi kualitas hidup dan produktifitas seseorang. Hipertensi relatif lebih tinggi terjadi pada wanita dengan prevalensi $28,8 \%$. Salah satu penyebabnya adalah kurangnya pengetahuan dan pemberian KIE tentang bahaya penggunaan KB hormonal pada akseptor KB hormonal yang memiliki hipertensi dan penggunaan secara jangka panjang. Penelitian bertujuan mengetahui pengaruh pemberian KIE menggunakan buku saku pada akseptor KB hormonal. Penelitian mengunakan kuantitatif semu experimental dengan one grup pre-test post-test. Pengambilan sampel menggunakan simple random sampling pada 100 akseptor KB hormonal di wilayah kerja Puskesmas Soreang yang memenuhi kriteria inklusi dan ekslusi. Pengumpulan data menggunakan kuesionar dianalisis menggunakan Uji Wilcoxon untuk mengetahui perbedaan pengetahuan sebelum dan sesudah diberikan perlakuan. Hasil penelitian $p$-value $=(, 000)$ terdapat pengaruh yang bermakna pada pengetahuan akseptor KB hormonal di Puskesmas Soreang sebelum dan sesudah diberikan intervensi. Pemberian KIE dengan buku saku meningkatkan pengetahuan akseptor KB hormonal tentang risiko hipertensi pada akseptor KB hormonal di Puskesmas Soreang.Diharapkan adanya peningkatan pengetahuan akseptor KB dalam memilih jenis kontrasepsi yang sesuai dengan keadaannya.
\end{abstract}

Kata kunci : KB Hormonal, Akseptor, Buku Saku, Hipertensi

\begin{abstract}
Hypertension is a non-contagious disease, has a high mortality rate, and affects a person's quality of life as well as productivity. Hypertension is most prevalent in female (28,8\%). The dosage of estrogen and progesteron hormone in hormonal contraception is suspected as the main cause of the increased blood pressure so a long term usage of hormonal contraception is not recommended. Lack of knowledge regarding hormonal contraception is one of the causes why there currently are many Keluarga Berencana's (KB) acceptors who still use a long term hormonal contraception. This study aims to improve hormonal contraception acceptor's knowledge by providing a pocket book so the main goal of a Healthy and Prosperous KB may be achieved. pre-experimental study with one group pre-test and post-test method. A total of 100 respondents who are hormonal contraception acceptors in Soreang Public Health Center were chosen by using the simple random sampling technique. The data collected in this study was obtained through questionnaire. Wilcoxon analysis was used to determine the deviation of the knowledge value before and after the education. The survey resulted that there is improvement of knowledge of $K B$ acceptor after being given a pocket book for hormonal contraception user with a p-value=(,000). The distribution of pocket book appeared to significantly increase the knowledge of hormonal contraception acceptor regarding the risks of hypertension. Along with their increased knowledge, it is hoped that hormonal contraception acceptors will be more careful on choosing the type of contraception which is suitable for their condition.
\end{abstract}

\section{Keywords: Hormonal Contraception, Acceptor, Pocket Book, Hypertension}




\section{PENDAHULUAN}

Salah satu penyakit tidak menular yang banyak ditemukan pada masyarakat saat ini adalah hipertensi. Berdasarkan data Riset Kesehatan Dasar tahun 2013 hipertensi merupakan penyebab kematian ke-3 di negara Indonesia. Provinsi Jawa Barat sendiri berada di urutan ke-4 dengan hipertensi tertinggi di negara Indonesia. Kabupaten Bandung menempati posisi ke-6 dengan kasus hipertensi tertinggi.

Penelitian dilakukan di Puskesmas Soreang berdasarkan data dari Puskesmas Soreang (2015), penyakit hipertensi menjadi urutan ke 2 dari 15 penyakit terbanyak yang melakukan kunjungan ke Puskesmas Soreang. Seseorang dikatakan hipertensi bila hasil tekanan darah sistolik $\geq 140 \mathrm{mmHg}$ atau tekanan darah diastolik $\geq 90 \mathrm{mmHg}$.

Berdasarkan data Riset Kesehatan Dasar (2013), prevalensi hipertensi lebih tinggi pada wanita dibandingkan pria. Data mencatat prevalensi hipertensi pada wanita $28,8 \%$ lebih tinggi dibandingkan pria dengan prevalensi $22,8 \%$. Terdapat beberapa faktor risiko yang berkontribusi terhadap kenaikan tekanan darah pada wanita diantaranya riwayat hipertensi, gaya hidup termasuk pola konsumsi lemak dan garam tinggi, obesitas sentral, dan penggunaan kontrasepsi hormonal. Penggunaan kontrasepsi hormonal yang mengandung hormon estrogen dan progesteron dapat menyebabkan terjadinya peningkatan tekanan darah. Penelitian yang dilakukan oleh Anisa (2018), menemukan bahwa di negara Indonesia terdapat 5829 wanita sebagai akseptor $\mathrm{KB}, 81,6 \%$ diantaranya menggunakan kontrasepsi hormonal dan $15,46 \%$ diantaranya memiliki hipertensi.

Data Pemerintah Kabupaten Bandung (2017), jumlah peserta KB di Kabupaten Bandung tercatat sebanyak 585.742 akseptor $(82,29 \%)$ dari Pasangan Usia Subur (PUS) sebesar 711.750. Akseptor KB di Kabupaten Bandung, masih bertumpu pada penggunaan kontrasepsi hormonal diantaranya suntik (53\%) dan pil (23\%).

Pemilihan metode kontrasepsi sangat berpengaruh kepada keputusan akseptor KB itu sendiri yang dimana dapat dipengaruhi oleh tingkat pengetahuan, ekonomi, motivasi, dan pemberian Komunikasi Informasi dan Edukasi (KIE) oleh petugas kesehatan. KIE adalah suatu kegiatan dimana terjadi proses komunikasi dengan pemberian informasi yang mempercepat terjadinya perubahan perilaku dari masyarakat. Adapun KIE KB dapat berupa penyuluhan dengan pemberian informasi dengan media cetak dan media visual serta kunjungan oleh petugas KB. Penelian sebelumnya mendapatkan hasil adanya hubungan antara tingkat pendidikan, pengetahuan, dan pemberian KIE $\mathrm{KB}$ oleh petugas kesehatan dalam meningkatkan pengetahuan. (Laras, 2015).

KIE yang diberikan oleh petugas kesehatan sangat berpengaruh pada tepat atau tidaknya peserta KB untuk menentukan jenis kontrasepsi yang akan digunakan. Hasil penelitian para ahli, pengetahuan yang diperoleh dari indra penglihatan ialah $75-87 \%$ dan $13-25 \%$ diperoleh melalui alat indra lainnya. Oleh 
karena itu KIE dalam penelitian ini menggunakan media cetak dalam bentuk buku saku. Buku saku juga dapat digunakan sebagai alat bantu referensi pelengkap yang digunakan sebagai media pada proses pembelajaran. Penelitian sebelumnya mendapatkan hasil terdapat pengaruh penggunaan media cetak buku saku terhadap peningkatan pengetahuan(Ahmady,2018).Media cetak merupakan media yang paling sering digunakan dan mudah untuk dijangkau. Materi cetak juga menempati posisi penting dalam pendidikan kesehatan karena memberikan pesan jelas yang dapat dibawa serta tidak membutuhkan internet untuk mengaksesnya.

Berdasarkan uraian diatas peneliti tertarik untuk meneliti Pengaruh KIE menggunakan Buku Saku Terhadap Peningkatan Pengetahuan Akseptor KB Hormonal di Puskesmas Soreang. Oleh karena itu penelitian ini bertujuan untuk mengetahui pengetahuan akseptor $\mathrm{KB}$ hormonal sebelum dan sesudah diberikan KIE dengan buku saku dan melihat pengaruh pemberian KIE menggunakan buku saku terhadap peningkatan pengetahuan akseptor $\mathrm{KB}$ hormonal tentang efek samping hipertensi pada penggunaan KB hormonal.

\section{METODOLOGI PENELITIAN}

Penelitian ini dilakukan di Puskesmas Soreang Kabupaten Bandung dimulai dari bulan Juli hingga September 2019 dan mendapat persetujuan Komite Etik Penelitian Kesehatan Fakultas Kedokteran Universitas Padjajaran yang tertera dalam surat nomor
366/UN6.KEP/EC/2019. Sampel Desain penelitian yang digunakan dalam penelitian ini adalah semu experimental design (one grup) pretest-posttest. Populasi dalam penelitian ini adalah akseptor KB hormonal yang terdaftar di puskesmas soreang. Sample berjumlah 100 orang akseptor $\mathrm{KB}$ yang memenuhi kriteria inkulisi dan ekslusi. Adapun kriteria inklusi dalam penelitian ini adalah sebagai berikut: 1)akseptor KB hormonal (pil,suntik,implan), 2) berdomisili di wilayah kerja puskesmas soreang kabupaten bandung, 3) WUS yang bersedia menjadi responden. Kriteria eksluasi dalam penelitian ini adalah sebagai berikut: 1) tidak bisa membaca, 2) dalam keadaan sakit.

Pengambilan sample dalam penelitian ini menggunakan metode simple random sampling dengan cara mengundi akseptor KB hormonal yang daftar ke poli KB puskesmas soreang dengan menggunakan aplikasi random. Subjek penelitian diberikan lembar informed consent sebelum dilakukan pengundian. Nama-nama responden akan diambil dari pendaftaran hari tersebut di poli $\mathrm{KB}$ puskesmas soreang, nama yang terpilih akan menjadi sampel penelitian mengisi lembar kuesioner berupa pre-test dan diberikan intervensi berupa buku saku. 1 minggu kemudian, dilakukan kunjungan kerumah responden untuk mengambil data posttest.

Dilakukan uji statistic dengan menggunakan SPSS 22.0 for windows. Uji normalitas menggunakan uji Shapiro-Wilk untuk mengetahui sebaran data. Uji statistic Wilcoxon digunakan untuk mengetahui 
pengaruh pemberian buku saku efek samping hipertensi pada penggunaan $\mathrm{KB}$ hormonal terhadap peningkatan pengetahuan akseptor KB hormonal.

\section{HASIL DAN PEMBAHASAN}

Penelitian ini bertujuan untuk mengetahui pengaruh pemberian buku saku tentang efek samping hipertensi pada penggunaan KB hormonal terhadap peningkatan pengetahuan akseptor KB. Responden penelitian ini adalah wanita usia subur yang menggunakan kontrasepsi hormonal yang berkunjung ke Puskesmas Soreang Kabupaten Bandung pada periode Juli-September tahun 2019. Jumlah responden yang mengikuti penelitian diperoleh berdasarkan kriteria inklusi dan ekslusi sebanyak 100 orang. Seluruh responden diberikan lembar informed consent terlebih dahulu dan seluruh responden diberikan perlakuan yang sama. Jarak pemberian 'pre-test 'dan diberikan perlakuan berupa buku saku dengan diberikan post-test selama satu minggu.

Tabel 1. Karakteristik Akseptor KB Hormonal Di Puskesmas Soreang

\begin{tabular}{cccc}
\hline Karakteristik & & Frekuensi & $\%$ \\
\hline Usia & $<20$ thn & 1 & 1 \\
& $20-35$ thn & 61 & 61 \\
\multirow{3}{*}{ Pendidikan } & $>35$ thn & 38 & 38 \\
& SD & 10 & 10 \\
& SLTP & 31 & 31 \\
& SLTA & 52 & 52 \\
& Perguruan tinggi & 7 & 7 \\
\hline TOTAL & & $\mathbf{1 0 0}$ & $\mathbf{1 0 0} \%$ \\
\hline
\end{tabular}

Berdasarkan tabel 1 diketahui akseptor $\mathrm{KB}$ hormonal di Puskesmas Soreang dominan berusia 20-35 tahun. Dari segi pendidikan akseptor KB hormonal di Puskesmas Soreang dominan dengan pendidikan SLTA.

Tabel 2. Distribusi Frekuensi Pengetahuan Akseptor KB Hormonal di Puskesmas Soreang.

\begin{tabular}{ccccc}
\hline & \multicolumn{2}{c}{ Pre Test } & \multicolumn{3}{c}{ Post Test } \\
\cline { 2 - 5 } Pengetahuan & n & $\%$ & n & $\%$ \\
\cline { 2 - 5 } & 15 & 15 & 30 & 30 \\
Baik & 69 & 69 & 70 & 70 \\
Cukup & 16 & 16 & 0 & 0 \\
Kurang & 100 & 100 & 100 & 100 \\
\hline Jumlah & 100 & & & \\
\hline
\end{tabular}

Tabel 2 menunjukan bahwa sebelum diberikan perlakuan sebanyak 16 orang akseptor KB hormonal (16\%) memiliki pengetahuan yang kurang, setelah diberikan perlakuan tidak ada akseptor KB hormonal yang memiliki pengetahuan kurang.

Tabel 3. Distribusi Frekuensi Karakteristik Dengan Pengetahuan Pre-Test

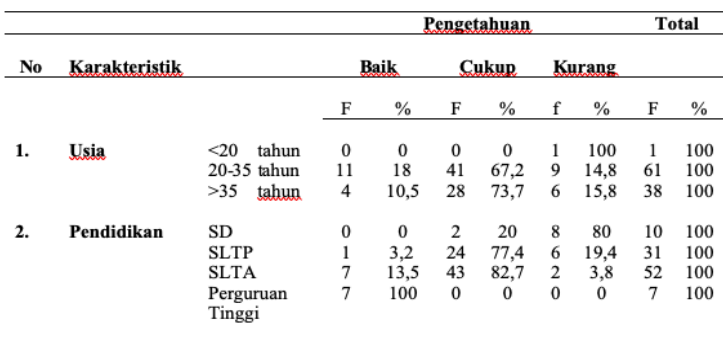

Berdasarkan tabel 3 diketahui sebelum diberikan perlakuan, akseptor KB hormonal yang memiliki pengetahuan cukup berdasarkan karakteristik usia yaitu akseptor KB dengan usia 20-35 tahun sebanyak 41 orang $(67,2 \%)$. Sedangkan karakteristik berdasarkan Pendidikan terakhir SLTA. Kategori pengetahuan terbanyak 43 orang $(82,7 \%)$ adalah pengetahuan cukup. 
Tabel 4. Distribusi Frekuensi Karakteristik Dengan Pengetahuan Post-Test

\begin{tabular}{|c|c|c|c|c|c|c|c|c|}
\hline \multirow{3}{*}{ No } & \multirow{3}{*}{ Karakteristik } & & \multicolumn{4}{|c|}{ Pengetahuan } & \multicolumn{2}{|c|}{ Total } \\
\hline & & & & & & kup & & \\
\hline & & & $\mathrm{F}$ & $\%$ & $\mathrm{~F}$ & $\%$ & $\mathrm{~F}$ & $\%$ \\
\hline 1. & Usia & $\begin{array}{l}<20 \text { tahun } \\
20-35 \text { tahun } \\
>35 \text { tahun }\end{array}$ & $\begin{array}{c}0 \\
21 \\
7\end{array}$ & $\begin{array}{c}0 \\
34,4 \\
18,4\end{array}$ & $\begin{array}{c}1 \\
40 \\
31\end{array}$ & $\begin{array}{l}100 \\
65,6 \\
81,6\end{array}$ & $\begin{array}{c}1 \\
61 \\
38\end{array}$ & $\begin{array}{l}100 \\
100 \\
100\end{array}$ \\
\hline 2. & Pendidikan & $\begin{array}{l}\text { SD } \\
\text { SLTP } \\
\text { SLTA } \\
\text { Perguruan } \\
\text { Tinggi }\end{array}$ & $\begin{array}{c}0 \\
2 \\
20 \\
6\end{array}$ & $\begin{array}{c}0 \\
6 \\
38,4 \\
85,7\end{array}$ & $\begin{array}{c}10 \\
29 \\
32 \\
1\end{array}$ & $\begin{array}{c}100 \\
94 \\
61,6 \\
14,3\end{array}$ & $\begin{array}{c}10 \\
31 \\
52 \\
7\end{array}$ & $\begin{array}{l}100 \\
100 \\
100 \\
100\end{array}$ \\
\hline
\end{tabular}

Berdasarkan tabel 4 dapat diketahui bahwa setelah diberikan perlakuan akseptor $\mathrm{KB}$ hormonal yang memiliki pengetahuan baik berdasarkan karakteristik usia yaitu berusia 2035 tahun sebanyak 21 orang $(34,4 \%)$. Dari segi pendidikan terakhir SLTA terdapat sebanyak 20 orang $(38,4 \%)$ yang memiliki pengetahuan baik.

Tabel 5. Pengaruh Buku Saku Terhadap Pengetahuan Akseptor KB Hormonal Di Puskesmas Soreang

\begin{tabular}{cccc}
\hline \multirow{2}{*}{ Variabel } & \multicolumn{2}{c}{ Pengukuran } & \multirow{2}{*}{ Nilai p } \\
\cline { 2 - 3 } & Pre-test & Post-test & \\
\hline Pengetahuan & & & 0,000 \\
Rata-rata (SD) & $13,48(2,303)$ & $16,95(1,471)$ & \\
Median & 14,00 & 16,00 & \\
Rentang & $7-19$ & $16-20$ &
\end{tabular}

Berdasarkan tabel 5, hasil uji statistika dengan menggunakan uji Wilcoxon diperoleh nilai signifikan $\mathrm{p}=0,000$ dengan demikian data menunjukan terdapat perubahan bermakna antara sebelum dan setelah pemberian buku saku tentang efek samping hipertensi pada penggunaan $\mathrm{KB}$ hormonal dapat meningkatkan pengetahuan akseptor KB hormonal.

Penelitian ini bertujuan untuk mengetahui pengaruh pemberian buku saku terhadap peningkatan pengetahuan akseptor $\mathrm{KB}$ hormonal. Hal ini menunjukan bahwa akseptor KB hormonal di Puskesmas Soreang tergolong kedalam usia reproduksi sehat. Usia reproduksi sehat adalah keadaan sehat secara fisik, mental, dan sosial secara utuh, tidak semata-mata bebas dari penyakit atau kecacatan yang berkaitan dengan sistem, fungsi, dan proses reproduksi. Pendidikan akseptor KB hormonal pada penelitian ini dominan dengan pendidikan terakhir SLTA sebanyak 52\%. Penelitian Arisna (2016), menjelaskan pendidikan mempengaruhi pengetahuan, bukan hanya memberikan informasi tentang sesuatu yang ingin diketahui tetapi memberikan pola pikir. Seseorang yang mempunyai pendidikan lebih tinggi akan lebih mudah menerima informasi yang disampaikan.

Hasil jawaban dari kuesioner saat pretest didapatkan topik yang belum dipahami oleh akseptor KB hormonal yaitu mengenai batasan tekanan darah yang termasuk hipertensi dan komplikasi apabila akseptor KB hormonal memiliki hipertensi. Pada penelitian ini responden mendapatkan buku saku untuk difahami dan dibaca dirumah. Saat pengambilan data post-test terdapat peningkatan jumlah pengetahuan pada topik tersebut, sehingga dapat disimpulkan bahwa pengetahuan merupakan hasil mengingat suatu hal dan terjadi setelah responden membaca buku saku yang menarik dengan gambar dan penjelasan yang singkat serta jelas sehingga mudah dipahami.

Terdapat perbedaan pengetahuan akseptor KB hormonal di Puskesmas Soreang sebelum 
dan sesudah diberikan buku saku tentang efek samping hipertensi pada penggunaan $\mathrm{KB}$ hormonal yang ditunjukan dengan perbedaan rata-rata pre-test sebesar 13,48 meningkat menjadi post-test 16,95. Hal tersebut menunjukan bahwa terdapat pengaruh pemberian buku saku terhadap peningkatan pengetahuan.

Hasil Penelitian ini juga sejalan dengan penelitian Ahmady (2018), dimana dalam penelitian tersebut terdapat pengaruh penggunaan media cetak berupa buku saku terhadap peningkatan pengetahuan pendamping ibu nifas. Penelitian tersebut menyebutkan bahwa media cetak merupakan media yang paling sering digunakan dan mudah untuk dijangkau contohnya buku saku. Buku saku menempati posisi penting dalam pendidikan kesehatan karena memberikan pesan jelas dan praktis yang membuat pembacanya membaca kapan saja tanpa membutuhkan internet untuk mengaksesnya.

\section{KESIMPULAN}

Hasil penelitian yang telah dilakukan pada akseptor KB hormonal di Puskesmas Soreang:

1. Hasil penelitian menunjukan karakteristik akseptor KB hormonal di Puskesmas Soreang dengan frekuensi terbanyak berada pada usia 20-35 tahun sebesar 61\% dan pendidikan terakhir SLTA sebanyak 52\%.

2. Hasil penelitian menunjukan adanya peningkatan skor pengetahuan akseptor KB hormonal di Puskesmas Soreang yang ditunjukan dengan perbedaan rata-rata pretest sebesar 13,48 meningkat menjadi 16,95 .

3. Hasil penelitian menunjukan pengetahuan berdasarkan karakteristik usia responden dengan frekuensi usia 20-35 tahun yang memiliki nilai pengetahuan baik sebesar $18 \%$ meningkat menjadi $34,4 \%$. Pengetahuan berdasarkan karakteristik pendidikan dengan frekuensi pendidikan SLTA yang memiliki pengetahuan baik sebesar 13,5\% meningkat menjadi 38,4\%

4. Hasil penelitian menunjukan diperolah nilai $p$-value $=(, 000)$ yang dapat diartikan secara statistik menunjukan terdapat pengaruh yang bermakna pada pengetahuan akseptor KB hormonal di Puskesmas Soreang sebelum dan sesudah diberikan media berupa buku saku.

\section{DAFTAR PUSTAKA}

1. Ardiansyah, Fachri. Hubungan Penggunaan Kontrasepsi Suntik Tiga Bulanan Selama Satu Tahun Dengan Peningkatan Tekanan Darah. 2017;11(1):56-62.

2. Kementrian Kesehatan Republik Indonesia. Badan Peneliti Dan Pengembangan Riset Kesehatan Dasar. 2013.

3. Profil Kesehatan Provinsi Jawa Barat. Dinas Kesehatan Provinsi Jawa Barat.2016

4. Prima S. Peningkatan Kegiatan Prolanis Melalui Inovasi Kegiatan Dalam Mempengaruhi Kualitas Hidup Peserta Prolanis Di Puskesmas Soreang. Dinas Kesehatan Kabupaten Bandung. 2018.

5. World Health Organization. A Global Brief On Hypertension: Silent Killer, Global Public Health Crisis: World Health Day 2013. World Health Organization. 2013.

6. Pangaribuan , Lolong. Hubungan Penggunaan Kontrasepsi Pil Dengan 
Kejadian Hipertensi Pada Wanita Usia 15 49 Tahun Di Indonesia Tahun 2013 (Analisis Data Riskesdas 2013). 2015;25(2):89-96.

7. Olatunji L, Usman T, Seok Y, Kim. Biochemistry. Activation Of Cardiac Renin-Angiotensin System And Plasminogen Activator Inhibitor-1 Gene Expressions In Oral Contraceptive-Induced Cardiometabolic Disorder. 2017;123(1):18.

8. Kementrian Kesehatan RI. Profil Kesehatan Indonesia. 2017

9. Putripratama, Sofiain Y, Roesli. A17877 Epidemiology Of Hypertension In Indonesian Women, Ifls 5 Data. 2018;36:E343.

10.Suryanda. Analisis Faktor Resiko Hipertensi Sekunder Pada Pengguna Kontrasepsi Aktif Di Puskesmas Tanjung Agung Kabupaten Ogan Komering Ulu Sumatera Selatan. 2017;8(3):331

11.Fatmasari, Saraswati, Adi. Gambaran Penggunaan Kontrasepsi Hormonal Pada Kejadian Hipertensi (Studi Pada Wanita Pasangan Usia Subur Di Kelurahan Tembalang). 2018;6(1):344-8.

12.Demel, Kittner S, Ley SH, Mcdermott, Rexrode. Stroke Risk Factors Unique To Women. 2018;49(3):518-23.

13.Ahmady, Ashari. Efektifitas Buku Saku Dalam Meningkatkan Pengetahuan Pendamping Ibu Nifas Di Kabupaten Mamuju. 2018;4(2):122

14.Giribela, Nisenbaum, Moraes, Baracat. Effects Of A Combined Oral Contraceptive Containing $20 \mathrm{Mcg}$ Of Ethinylestradiol And $3 \mathrm{Mg}$ Of Drospirenone On The Blood Pressure, Renin-Angiotensin-Aldosterone System, Insulin Resistance, And Androgenic Profile Of Healthy Young Women. 2015;31(11):912-5.

15.Rahmawati, Nugraheni, Mawarni. Pengaruh Penggunaan Buku Saku Oleh Motivator Terhadap Pengetahuan Dan Keterampilan Motivator Dalam Mengatasi Permasalahan Pemberian ASI (di Kecamatan Sewon Kabupaten Bantul). 2015;3(2):64-70.

16.Sunaryo. Psikologi Untuk Keperawatan. EGC, Editor. Jakarta2014.
17.Kusuma. Hubungan Antara Metode Dan Lama Pemakaian Dengan Keluhan Kesehatan Subyektif Pada Akseptor. 2016;4(2):164-75.

18.Kisokanth, Ilankoon, Arulanandem. Assessment Of Knowledge On The Disease, Its Complications And Management Strategies Among Hypertensive Patients Attending Medical Clinics At Teaching Hospital, 